\title{
Editorial Foreword 76.3 (August 2017)
}

\section{Our Cover}

This month's cover illustration is an interior of a traditional Chosŏnjok, or Cháoxiănzú, house featured in the film The Yellow Sea (2010, dir. by Hongjin Na). The kitchen is on the ground level, a little lower than the heated floor in the rest of the house. It can be covered by wooden panels to convert the area to either a living room or a bedroom. This hybrid space is called “chŏngjugan” 鼎廚間. The house style was unique to farms in the Hamgyŏng-do region, and later transplanted into Manchuria and beyond during the massive Korean dispersion into China during the late nineteenth and early twentieth centuries. This still cut was extracted by author Suk Koo Rhee from the movie, and is used with permission.

\section{IN THIS IssUE}

This issue breaks from recent tradition in that its eight main pieces are all standalone research articles. There are no symposia or other kinds of clusters of essays, in other words, and none of the contributions fit into the Asia Beyond the Headlines, Trends, or Reflections categories. However, if they are uniform when it comes to genre and of being roughly the same length, they are nothing if not diverse in other ways. When taken together, they offer a reminder of the fact that high-quality work in Asian studies is now being done by scholars with ties to many different parts of the world and to many different disciplines. In terms of topics, the articles to come engage with everything from debates about the meaning of early human remains to the crafting of travel tales, and in the process introduce readers to the actions of individuals ranging from Zen monks to wartime munitions workers, from demographers and members of trade delegations who traveled between India and China during the 1950s to social workers active in twenty-first-century South Korea. The contributors include specialists in history, anthropology, sociology, science and technology studies (STS), and literature, and they are based everywhere from Seoul to Singapore, Toronto to Taipei, North America to the northeast of England.

The issue begins with a look far back into the past_-or rather an exploration of claims made about very early history. In “'Is Peking Man Still Our Ancestor?'-Genetics, Anthropology, and the Politics of Racial Nationalism in China," historian YInGHONG Cheng carries forward and adds new twists to an ongoing scholarly discussion of the way that political and scientific claims and priorities intersect in debates about early hominid remains. Engaging with past works on the meaning and politicization of "Peking Man," including an important book on the subject by Sigrid Schmalzer and a 
past Journal of Asian Studies article by Barry Sautman, Cheng sheds new light on the connections between archaeological findings, ideas about human origins, and contemporary Chinese nationalism.

Following this is an article that focuses on issues of language and translation in Tokugawa Japan. In this essay, "Speaking in Tongues? Daimyo, Zen Monks, and Spoken Chinese in Japan, 1661-1711," Reberah Clements explores the "cultivation of spoken Chinese learning and the patronage of Chinese émigrés by members of Japan's warrior elite." It is a work that moves across the borders between religious studies and the history of orality and language use, and that illustrates the complex ways that connecting oneself to a valued tradition can enhance one's status in a setting far removed from the original home of that tradition.

Moving forward in time, we come next to Yufen CHANG's "Spatializing Enlightened Civilization in the Era of Translating Vernacular Modernity: Colonial Vietnamese Intellectuals' Adventure Tales and Travelogues, 1910s-1920s." This essay engages with a set of works that involve a dizzying array of border crossings, for the writers drew inspiration from Chinese translations of Japanese texts, and, as Chang puts it, also "negotiated with" French Enlightenment ideas by "employing two East Asian literary tropes: the dangerous but exciting Rivers-and-Lake World ... and the peaceful and other-worldly Peach Blossom Spring utopia." Fueled by a mixture of "admiration for and anxiety regarding the French mission civilisatrice," they strove to craft works that would make use of ideas and a format they saw as worthy of emulation, but in the process created texts that were distinctively Vietnamese and would in some ways "surpass" in quality the "original models" that helped inspire them.

Next comes Benjamin Uchiyama’s “The Munitions Worker as Trickster in Wartime Japan," which traces the ways that a particular sort of laborer was alternately celebrated and mocked in wartime texts such as comic strips, newspaper editorials, and satirical commentaries. Drawing on comparative and theoretical work on the "trickster" figure, done by specialists in fields such as religious and ritual studies, and connecting his analysis to recent work that historians of Japan have done on consumerism and popular culture on the home front during World War II, Uchiyama illuminates the varied ways that Japanese from different walks of life projected their hopes and fears onto the figure of the munitions worker.

Following this is Ittry Aвraham's "From the Commission to the Mission Model: Technology Czars and the Indian Middle Class," a foray into STS. The author assesses the records of five different "strategic industries" in India in different periods: "atomic energy, space, electronics, biotechnology and telecommunications." He concludes that, despite the "persistence" of narratives that attribute "technological success" in areas such as these to the "extraordinary efforts of a single individual, a technology "czar," the reality is much more complex. In fact, "no single factor" can be used to explain how well or badly a given industry has fared.

In the next article, "Before 1962: The Case for 1950s China-India History," historian Arunabh Ghosh makes the case for moving beyond diplomatic concerns, narrowly defined, when thinking about the connections and interactions between Asia's two most populous countries during the first part of the Cold War. He does this in a wide-ranging essay that touches upon everything from a 1955 "Indian film week" for which "two million tickets were sold across twenty major Chinese cities" and a parallel 
"Chinese film festival held in India" during that same year; to exchanges of and competitions between sports teams from the two countries; to an Indian demographer's investigation into contraceptive use in Mao's China. While admitting that he is only showing readers "scratches on a vast surface," Ghosh demonstrates the value of moving beyond an approach to the two countries during this period that too often "remains mired in concerns related to border demarcations and the war of 1962."

The issue closes with two articles that deal with very different aspects of contemporary South Korea. The first is literary scholar Suk Koo RHEE's "Uncanny Hybridity and Nostalgia Politics in The Yellow Sea," which looks at the representation of Chinese migrants to South Korea who are of Korean ethnicity. Through a close reading of a single film, The Yellow Sea, the author crafts an argument about the various ways that the "uncanny" qualities of these particular migrants are handled in works of popular culture. Following this comes anthropologist JEsook Song's "Gendered Care Work as 'Free Labor' in State Employment: School Social Workers in the Education Welfare (Investment) Priority Project in South Korea." Based on interviews and drawing on feminist work focusing on other parts of the world, this article explores topics such as "recent unionization efforts by school social workers" and the way that the gendering of certain kinds of labor can contribute to patterns of exploitation.

\title{
Selected Forthcoming Articles in JAS 76.4 (November 2017)
}

\author{
Asia Beyond the Headlines
}

"Spoon Theory" and the Fall of a Populist Princess in Seoul HyejIN KIM

The Occult of Personality: Korea’s Candlelight Protests and the Impeachment of Park Geun-hye Jamie Doucette

\section{Presidential Address}

Things Fall Apart: Material Religion and the Problem of Decay

Laurel Kendall

JAS at AAS: The Flow of Migration Beyond the Nation

Engseng Ho, Rian Thum, Sunil Amrith, Jaeeun Kim, and Emma Teng

\section{Research Articles}

New Findings on the Indonesian Killings of 1965-66

Siddharth Chandra 


\section{Editorial Foreword}

Anatomy and the Reconfiguration of Life and Death in Republican China DAVID LUESINK

Lines of (In)Convenience: Sovereignty and Border-Making in Postcolonial South Asia, 1947-1965

Elisabeth Leake and Daniel Haines

Vietnamese Collaborationism in Vichy France

Charles Keith

The Journey towards "No Man’s Land": Interpreting the China-Korean Borderland within Imperial and Colonial Contexts

Nianshen Song 